\title{
BALLAST WATER: A REVIEW OF THE IMPACT ON THE WORLD
} PUBLIC HEALTH

\section{TAKAHASHI CK (1), LOURENÇO NGGS (1), LOPES TF (2), RALL VLM (3), LOPES CAM (3)}

(1) São Paulo State University, UNESP, São Vicente, São Paulo State, Brazil; (2) Santa Cecília University, Santos, São Paulo State, Brazil; (3) Department of Microbiology and Immunology, Botucatu Biosciences Institute, São Paulo State University, UNESP, Botucatu, São Paulo State, Brazil.

ABSTRACT: Since the nineteenth century ships have been using ballast water (BW) for safety, stability, propulsion and maneuverability, as well as to redress loss of fuel weight and water consumption, and to maintain structural stress at acceptable levels. Ballast water has been spreading many non-native species around the globe, but little is known about the extent and potential significance of ship-mediated transfer of microorganisms. The global movements of ballast water by ships create a longdistance dispersal mechanism for human pathogens that may be important in the worldwide distribution of microorganisms, as well as for the epidemiology of waterborne diseases. Only a few studies have been carried out on this subject, most of them involving ballast water containing crustacean larvae and phytoplankton. Specialized microbiological studies on these waters are necessary to avoid a repeat of what happened in 1991, when epidemic cholera was reported in Peru and rapidly spread through Latin America and Mexico. In July of 1992, Vibrio cholerae was found in the USA and the Food and Drug Administration (FDA) determined that it came from ballast water of ships whose last port of call was in South America. In Brazil, just a few studies about the subject have been performed. An exploratory study by the Brazilian National Health Surveillance Agency (Agência Nacional de Vigilância Sanitária - ANVISA) found in ballast water different microorganisms, such as fecal coliforms, Escherichia coli, Enterococcus faecalis, Clostridium perfringens, coliphages, Vibrio cholerae $\mathrm{O} 1$ and Vibrio cholerae non-O1. Until now, Brazil has been focusing only on organisms transported to its territory from other countries by ballast water, to avoid their establishment and dissemination in Brazilian areas. Studies that can assess the probability that water ballast carries pathogenic microorganisms are extremely important, as is the examination of ships that arrive in the country. Treatment of the human infections caused by BW exists but none is completely safe and efficient.

KEY WORDS: public health, ballast water, Vibrio cholerae.

CONFLICTS OF INTEREST: There is no conflict.

\section{CORRESPONDENCE TO:}

CARLOS ALBERTO DE MAGALHÃES LOPES, Departamento de Microbiologia e Imunologia, Instituto de Biociências, UNESP, Campus de Botucatu, 18618-000, Botucatu, SP, Brasil, Email: lopescam@ibb.unesp.br 


\section{INTRODUCTION}

Ships have always required ballast to operate successfully and safely. For centuries, they carried solid ballast in the form of rocks, sand and many other heavy materials. From the 1880s onward, ships increasingly used water for ballast, thereby avoiding time-consuming loading of solid materials and instabilities resulting from the shifting of solid ballast during a voyage. However, discharged ballast water (BW) may release organisms into the environment $(14,31,37)$. In addition, human activities are directly or indirectly resulting in an impoverishment of marine biodiversity, especially when wastes are discarted into sea without appropriate treatment, thereby disseminating pathogenic microorganisms via domestic and nosocomial sewers (17, $19,23,24)$. These can reach beaches, ports and areas of marine product cultivation, putting human communities at risk $(2,3,7,15,33)$.

Currently, it is known that BW discharge into sea is potentially the greatest accidental manner of introducing undesirable non-native organisms into ports throughout the world. Due to the great volume of water used as ballast in modern ships, the spreading of organisms around the globe has increased, causing damaging human health, biodiversity, fishing activities and marine farms (6, 9, 21, 33, 37, 39, 42).

The success of bioinvasion mediated by BW is a process of several steps (5). First, organisms must survive extreme conditions during transport and subsequently deballast. To adapt to new environment, the organisms need to be sufficiently numerous for reproduction, present a high level of competitiveness against possible antagonists, and their reproduction rate must be sufficient to compensate for the mortality that can occur during their dispersion (1). According to some authors, BW can transport bacteria (43), protists $(12,13)$, protozoa (14), algae, zooplankton, benthonic invertebrates and fishes among harbors $(6,27,43)$.

\section{PHYTOPLANKTON}

The introduction of non-native aquatic species into North America has been observed since the beginning of transoceanic travels. In fact, organisms representing almost all taxonomic groups have been introduced in several areas in the world (30). At least 57 species of organisms may have been introduced by BW in the USA and some of these cause ecological and economical impacts $(21,26,32,37)$. In this country, specifically, the scale of introduction of non-native species is enormous: 136 were detected in the Great Lakes, at least 43 of these since 1960 (30). Of 150 species of 
nonindigenous organisms that were discovered in the San Francisco Bay, at least 21 have been colonizing the bay since 1973. In the Coos Bay, Oregon, there are approximately 80 exotic species and in the Chesapeake Bay, approximately 15 (11). Phytoplankton are probably the most successful organisms transported in BW because they are small, ubiquitous and capable of surviving in the darkness of ballast tanks (some transform themselves into a sleeping cyst) $(27,40)$. Around 342 phytoplankton species, especially Cyanophyta, Dinoflagellata, Bacillariophyta and Chlorophyta were isolated in nine ships. In a single ship were also found 145 different species, 132 of which were diatomaceous.

Nevertheless, the most notable example of invasion that had great influence on an ecosystem was represented by the zooplankton Mnemiopsis leidyi in the Black Sea. This ctenophore was brought from the northwestern Atlantic Ocean accidentally in the 1980s, probably by BW. The organism spread to the north, to the Sea of Azov, and to the south, to the Marmara and Aegean Seas. In 1999, it reached the Caspian Sea where it is now expanding (38). In the Black and Azov Seas, its massive development rate led to a catastrophic decline not only of zooplankton, but also of pelagic fishes. Additionally, the successful development of $M$. leidyi has been explained by the absence of predators, the ability to compete with native consumers of zooplankton, such as Aurelia aurita, and also by $M$. leidyi predation on eggs and larvae of zooplankton-eating fish (38).

\section{BACTERIA}

Possibly, the least studied aspect of marine bioinvasions is the transfer of nonindigenous microorganisms $(10,18)$. Commercial ships have spread them around the globe, but little is known about the extension and significance of this transference. The global movement of BW creates a dispersal mechanism for worldwide long-distance distribution of human pathogens, which consequently increases the number of waterborne diseases, affecting humans, plants and other animals $(35,37)$.

The concern about the transmission of potentially pathogenic bacteria via BW began in 1992, when the Food and Drug Administration (FDA) and the Centers for Disease Control and Prevention (CDC) of the USA detected Vibrio cholerae in shellfishes collected from ballast tanks of many ships that had come from South America. The water samples investigated showed salinities of 12, 13, 14, 20 and 32 ppm, which 
indicates that the microorganism is capable of surviving in both estuarine and marine waters (28).

A study carried out by Delille and Delille (10) found the presence of enteric bacteria even in Antarctic ice. In January of 1991, a cholera outbreak was first detected in Peru and in September of the same year, it quickly dispersed throughout South America and Mexico. In June of 1992, the microorganism was detected in the USA after tests performed on the BW of several South American ships (28). Delille and Dellile (10) also mentioned that a cholera outbreak that had begun in Indonesia in 1961 had completed its global cycle in 1991 and that the same infection was introduced in the 1990s in Latin America by sea traffic.

Historically, most of the cholera outbreaks that happened in the world originated in coastal areas seasonally, especially during Spring and Autumn (8).

A study on 19 BW samples from cargo ships in the ports of Mobile (Alabama) Gulfport and Pascagoula (Mississippi) accomplished by MacCarthy and Kambathy (28), found Vibrio cholerae in five of them. The most recent stops for these ships were: Brazil, Colombia, Chile and Puerto Rico. According those authors, in July of 1991 the Committee of Protection of the Sea Atmosphere of the USA adopted a resolution entitled: "International Guidelines for the Prevention of Introduction of Undesirable Pathogens for the Discharge of Water of Ballast and Sediments of the Ships" (28). These guidelines were published with the investigation completed by MacCarthy and Kambathy (28) in the Federal Register of December $12^{\text {th }}, 1991$. The US Coast Guard asked agents and ship captains to accept and follow the recommendation that BW must be changed twice on the high sea to reduce the possibility of contamination of American coastal waters.

In 1991 and 1992 toxigenic Vibrio cholerae O1, serotype Inaba, biotype El Tor, was detected in non-potable water from five cargo ships docked in the Gulf of Mexico. Four of these ships carried BW from countries affected by cholera and the fifth from a non-infected area. The isolates were examined by gel electrophoresis and were very similar to the C6707 strain from the Latin American outbreak, but were significantly different from the endemic strain from the Gulf of Mexico (VRL1984), the sixth pandemic strain (569-B), and from the Vibrio cholerae 01 strain from ships that had returned from foreign ports (25).

A global effort driven by the FDA in association with the US Coast Guard and quarantine officials from the CDC, in those same years, showed that six of 109 
samples - obtained from more than 90 ships that had arrived from Latin America were contaminated with $V$. cholerae O1 serogroup. Ruiz (37) found V. cholerae in plankton samples from all studied ships, 93\% of which presented two serotypes (O1 and O139). The concentration of serogroup $\mathrm{O} 1$ was significantly higher than $\mathrm{O} 139$. In his investigation, Ruiz (37) also states that the coastal ecosystems are frequently invaded by BW microorganisms and this fact is due basically to three factors:

- the concentration of bacteria and virus exceeded the other taxonomic groups by an order of magnitude from 6 to 8 ;

- the biology of many microorganisms can facilitate the invasion, for instance, their high growth capacity, asexual reproduction, colony-forming abilities and;

- tolerance to a wide variation of environmental conditions, including salinity and temperature.

\section{RESEARCH IN BRAZIL}

Brazil possesses about $8,000 \mathrm{~km}$ of coastline with 89 commercial ports and terminals that receive ships, constituting a commercial sea traffic that grows every year. Approximately $95 \%$ of all Brazilian external trade is conducted by sea (39).

The protection of the marine ecosystem is an obligation of several ministries, including Environment, Transportation, Tourism and Navy. The Ministry of the Environment is responsible for managing the process that integrates coastal waters with the high seas, including biodiversity and impact of aquatic organisms transported by BW. The Ministry of Health is also involved in this activity, accomplishing the service of sanitary inspection responsible for preliminary control of diseases in the ships.

Considering that ships usually take on water to fill their ballast tanks close to estuaries, they can carry various pathogenic organisms. Since the structure of Brazilian basic sanitation is precarious in a large part of the country with widespread discarding of domestic and nosocomial sewage into estuaries and onto beaches, the probability of transporting pathogenic microorganisms from this environment is dangerously high and constitutes a potential public health hazard (2).

ANVISA (2) concluded an exploratory study to identify and characterize pathogenic agents in BW. Corroborating results were obtained in many of the 99 collections from nine Brazilian ports. In this investigation, researchers found in $71 \%$ of the BW samples approximately $10^{3}$ to $10^{6}$ CFU/L. V. cholerae (31\%), fecal coliforms (13\%), 
Escherichia coli (5\%), fecal enterococci (22\%), Clostridium perfringens (15\%), coliphages (29\%), V. cholerae O1 (7\%), V. cholerae NAG (23\%) and plankton (21\%) were also observed.

However, it was also noticed that $62 \%$ of the ships, whose commanders declared to have changed BW in oceanic waters, according to the International Maritime Organization (IMO), probably did not change it or did so partially, because the BW of their ships showed a salinity level lower than 32 ppm. In 1991, V. cholerae was detected in Latin America and until the present date, it has caused more than 1.2 million cases of cholera, resulting in 12,000 deaths $(23,24)$. In Brazil, the outbreak showed the largest number of cases during 1993 and 1994. More recently, in 1999, 467 cases were confirmed on the coast of Parana State (Paranagua) (2).

\section{PREVENTIVE TREATMENTS}

In the 1980s, an international effort was made to research treatment options for BW. There were some concerns that the possible presence of viruses and bacteria in BW could show a real risk, although they were usually considered a secondary worry in all international operations and, consequently, the vast majority of the technologies for the treatment of BW did not include those microorganisms (36).

This subject has carried a considerable discussion and debate due to the several treatment options, some of them rejected or refined, in basis of its impracticability or lack of a good performance (13). In addition, these alternatives must take into account costs, safety, environmental risk and effectiveness (34). Silva et al. (39), however, mention that a treatment that covers all these subjects and shows $100 \%$ of efficiency does not exist.

Actually, there are two treatment options for BW: physical and chemical.

\section{Physical}

This kind of treatment employs only mechanical efforts without any type of chemical agents. Some examples of physical treatment are: change of BW in the oceanic waters; filtration; ultraviolet irradiation; heat; electrical fields; and gas super saturation (39).

I) Change of BW in oceanic waters 
This technique is very efficient (depth above 500 meters) $(4,34,39)$, although there are various limitations associated to it. The method involves the substitution of organisms from coastal areas in open sea (that presents high salinity concentration, approximately 30 to $34 \mathrm{ppm}$ ), which limits the organisms survival due to their intolerance to salt. However, in coastal trips the effectiveness of exchanging BW would be cancelled, since the ships would substitute its BW with similar water, to which the organisms are adapted (3). Besides, the change of BW in transoceanic trips could overload the hull, affecting its stability and structure, and putting crew's life at risk (39).

The conventional methods of exchanging BW in high sea are:

- Total deballast and subsequent ballast shipment: is the simplest and most effective technique of exchanging BW, since it eliminates the whole content, practically. However, it presents risks for the ship stability and for the crewmembers, because the maneuvers must be accomplished in sequences, i.e., a tank or pairs of tanks per time.

- Continuous flow: consists of changing the BW without the complete emptying of the tanks and filling them, at the same time, with clean water, in an amount three times larger than the volume of the tank. This method is more effective than the previous, since the ship is not exposed to safety risks, because there is constant maintenance of water exit and entry. However, the crewmembers are submitted to the polluted water and to the excessive pressure in the ballast tank.

- Tank overflow: is similar to continuous flow. Water is pumped in for a certain period and its excess overflows through the superior part. Although this technique guarantees stability to the ship, it reduces the effectiveness of the elimination of organisms; especially those sit on the bottom.

- Brazilian method of dilution: was conceived by naval engineers of Petróleo Brasileiro S.A. (Petrobras) as a system for the oil tankers. The goal is to supply a technical condition for the preservation of the sea environment, the prevention of the pollution and the complete safety of the ship. The basic concept of this method involves the shipment of the ballast tank and, simultaneously, its discharge by the bottom using the same flow. The main advantage of this method is to maintain appropriate levels of effort in the 
structure and stability of the ship, by not unloading the ballast tanks completely. Neither the tanks are submitted to an excessive internal pressure on their structures and nor the crewmembers are exposed to the problems and risks mentioned above. The method still facilitates the removal of sediments of the tanks (29).

\section{II) Filtration}

Different types of filters are used for the retention of a large number of organisms. The method also avoids the entrance of larger organisms in the ballast tanks. However, the great amounts of water that deposits organic matter on the screens of the filters are challenges in its use. The $\mathrm{pH}$ can be easily adjusted to supply great conditions in the removal of residues of oxidizers and disinfectants.

\section{III) Ultraviolet irradiation}

This method works for the elimination of microorganisms, but not for larger organisms as protozoa, mushrooms and algae. In the last case, ultraviolet (UV) radiation is associated with filtration (20). Wright et al. (44) found out that the bacterial counting after UV treatment increased, due to the destruction of phytoplankton and zooplankton which increases the available nutrients for bacteria.

\section{IV) Heat}

Heat is effective but there is a lack of studies concerning the amount heat that is necessary to eliminate a wide range of contaminant organisms. Vibrio cholerae is inactivated when heated to $73^{\circ} \mathrm{C}$ for 30 seconds or to $65^{\circ} \mathrm{C}$ for 120 seconds. Hepatitis virus needs $90^{\circ} \mathrm{C}$ for 60 seconds for inactivation. And most of thermotolerant organisms need heating at $90^{\circ} \mathrm{C}$ for 60 seconds to be eradicated; the exception is Clostridium perfringens (41).

\section{V) Electrical fields}

The technique does not have conclusive results, although Leffler et al. (22) observed the elimination of $95 \%$ of the biota (bacteria and protists) in the BW with this treatment. 
This process produces in BW a reduction of the pressure and formation of bubbles, provoking hemorrhagic effects and clot in the organisms, killing them. Its efficiency varies according to the groups of organisms and it is not able to liquidate virus, algae, bacteria, protozoan and algal cysts (44).

\section{Chemical}

This kind of BW treatment uses chemical substances as chlorates, borates, iodides, ozone, hydrogen peroxide, organic compounds, ionization, copper ions and adjustment in the $\mathrm{pH}$ and in the salinity for eradication of organisms (45).

\section{Ozonization}

The process is usually used in the treatment of drinking and industrial water. When it is employed in seawater, it reacts with the chlorine producing several corrosive substances. Since it is a very expensive process, it is unfeasible (44).

\section{Deoxigenization}

Restriction of oxygen causes the death of several animals, as fish, invertebrate larvae and aerobic bacteria. It is considered effective against Dinoflagellata, cysts, anaerobic bacteria and several benthonic organisms (44).

\section{Chlorine}

This treatment has proven its efficiency in fresh water. It presents as advantages easy application and handling, low cost and the capacity to treat great volumes of water. The method is already used on board of ships, but not for treatment in the ballast tanks, although some countries, like Brazil, have adopted it in the treatment of BW. Recent studies demonstrated that high concentrations of chlorine can generate poisonous substances, although it seems to be the most suitable way for treating BW due to its efficiency in low concentrations and in any $\mathrm{pH}$ (45). Chlorination with 5 $\mathrm{mg} / \mathrm{L}$, can kill $99.85 \%$ of anaerobic bacteria, $100 \%$ of $V$. cholerae and $85.2 \%$ of $E$. coli and with $20 \mathrm{mg} / \mathrm{L}$ can eradicate almost all the bacteria.

\section{Globallast}

A global project entitled "Removal of Barriers for the Implementation of the Control of the Water of Ballast and Measures of Administration in Developing Countries" 
(Removal of Barriers to the Effective Implementation of Ballast Water Control and Management Measures in Developing Countries) or simply "Global Programme of Administration of Water of Ballast - GloBallast" was elaborated by the IMO with the support of the United Nations Development Programme (UNDP) and the marine transportation industry, and subsidized by the Global Environment Fund (GEF), with the purpose of reducing the transfer of exotic marine species via BW (20).

The program had begun in March of 2000 and lasted four years, until December of 2004. Its objective was to aid the developing countries to implement the measures of voluntary character foreseen in the Resolution A.868 (20). These guidelines are also included in the International Convention for the Control and Management of Ships' Ballast Water and Sediment, adopted by the Diplomatic Conference of IMO in February of 2004 (20).

In this context, an institutional reinforcement, including technical support and training activities, was offered for the BW executive administration in six pilot countries, specifically in the ports of Sepetiba (Brazil), Dalian (China), Mumbai (India), Kish Island (Iran), Odessa (Ukraine) and Bay of Saldanha (South Africa), chosen as representative regions of the developing world.

According to a briefing paper from the Programme Coordination Unit (16), the GEF/UNDP/IMO Global Ballast Water Management Programme (GloBallast), whose objective is to assist developing countries in implementing measures to minimize the adverse impacts of aquatic invasive species transferred by ships in BW, has begun a new phase, following the successful initial execution of the five-year US\$10.2 million project by IMO.

The preparatory phase of the new project, to be known as GloBallast Partnerships, was initiated on April $1^{\text {st }}, 2005$, with funding of around US $\$ 700,000$ from the Global Environmental Facility (GEF). This preparatory project was executed by IMO over a period of 18 months and provided the groundwork for the full-scale GloBallast Partnerships project (full title: "Building Partnerships to Assist Developing Countries to Reduce the Transfer of Harmful Aquatic Organisms in Ships' Ballast Water"). The main objective was to assist particularly vulnerable countries or regions to enact legal and policy reforms to meet the objectives of the International Convention for the Control and Management of Ships' Ballast Water and Sediments, adopted by IMO in February 2004 (16).

Among the main activities proposed to each country were: 
- to build regional partnership towards effective implementation of global regulations on BW management and control;

- to undertake port base-line surveys and initial risk assessments to provide a clear understanding of the level and types of risks of introductions that each region faces, as well as the most sensitive resources and values that may be threatened, and the management response required;

- to develop and implement communication, education and awareness raising programmes about BW as a vector for transfer of the invasive marine species;

- formation of inter-ministerial country task forces;

- to implement national compliance monitoring and enforcement systems to ensure maximum compliance with the regulations on BW management.

The analysis of the specific bibliography allows us to highlight the following observations:

- the most appropriate technique for preventing the spread of non-native species is the change of BW in high sea;

- many ships do not follow this procedure, since it is effective just in long distance trips;

- if the change of BW is associated with the load of water for ballasts in areas previously determined, there will be a decrease in the probability of spreading potentially pathogenic organisms;

- there is a scarce number of microbiological studies accomplished on BW in the globe, mainly in Brazil, where there is only one report by ANVISA;

- it is undeniable that larger efforts and investigations for preventing the spread of pathogenic and non-native organisms via BW are necessary. 


\section{REFERENCES}

1 BARLOW ND., KEAN LM. Resource abundance and invasiveness: a simple model. Biol. Invasions., 2004, 6, 261-8.

2 BRASIL. Ministério da Saúde. Agência Nacional de Vigilância Sanitária. Água de lastro. Brasília: Projetos GGPAF, 2002.

3 BRIGHT C. Invasive species: pathogens of globalization. Foreign Policy, 1999, $166,50-64$.

4 CANGELOSI A. Ballast water management: developments in policy and technology. In: PEDERSON J. Ed. NATIONAL CONFERENCE ON MARINE BIOINVASIONS, 1, Cambridge, 1999. Proceedings... Cambridge: Massachusetts Institute of Technology, Sea Grant College Program, 1999. p.273-7.

5 CARLTON JT. Pattern, process, and prediction in marine invasion ecology. Biol. Conserv., 1996, 78, 97-106.

6 CARLTON JT., GELLER JB. Ecological roulette: the global transport of nonindigenous marine organisms. Science, 1993, 261, 78-82.

$7 \mathrm{CHU} \mathrm{KH.,} \mathrm{TAM} \mathrm{PF.,} \mathrm{FUNG} \mathrm{CH.,} \mathrm{CHEN} \mathrm{QC.} \mathrm{A} \mathrm{biological} \mathrm{survey} \mathrm{of} \mathrm{ballast} \mathrm{water} \mathrm{in}$ container ships entering Hong Kong. Hydrobiologia, 1997, 352, 201-6.

8 COLWELL R., HUQ A. Marine ecosystems and cholerae. Hydrobiologia, 2001, 460, 141-5.

9 COOGAN J., BARRACATO J., BISSING A., CRAWFORD D., MORGAN G. UV disinfection of ballast water: effects of organism size on system scaling. In: PEDERSON J. Ed. NATIONAL CONFERENCE ON MARINE BIOINVASIONS, 1 , Cambridge, 1999. Proceedings... Cambridge: Massachusetts Institute of Technology, Sea Grant College Program, 1999. p.337-43.

10 DELILLE D., DELILLE E. Distribution of enteric bacteria in Antarctic seawater surrounding the Dumont d'Urville Permanent Station (Adélie Land). Mar. Pollut. Bull., 2000, 40, 869-72.

11 DOBBS F., CHOI KH. Inventory of microbes in ballast water of ships arriving in Chesapeake Bay. In: PEDERSON J. Ed. NATIONAL CONFERENCE ON MARINE BIOINVASIONS, 1, Cambridge, 1999. Proceedings... Cambridge: Massachusetts Institute of Technology, Sea Grant College Program, 1999. p.417-9.

12 GALIL B., HULSMANN N. Protist transport via ballast water - biological classification of ballast tanks by food web interactions. Eur. J. Protistol., 1997, 33, 244-53. 
13 GENOVESI P. Eradications of invasive alien species in Europe: a review. Biol. Invasions., 2004, 7, 127-33.

14 HAMER JP., MCCOLLIN TA., LUCAS IAN. Dinoflagellate cysts in ballast tank sediments: Between tank variability. Mar. Pollut. Bull., 2000, 40, 731-3.

15 HEGER T., TREPL L. Predicting biological invasions. Biol. Invasions. 2003, 5, 313-21.

16 INTERNATIONAL MARITIME ORGANIZATION. Programme Coordination Unit. Global Ballast Water Management Programme. London: IMO, 2002. Available from: http://www.imo.org.

17 JOACHIMSTHAL EL., IVANOV V., TAY JH., TAY STL. Flow citometry and conventional enumeration of microorganisms in ships' ballast water and marine samples. Mar. Pollut. Bull., 2003, 46, 308-13.

18 JOACHIMSTHAL EL., IVANOV V., TAY JH., TAY STL. Bacteriological examination of ballast water in Singapore Harbor by flow cytometry with FISH. Mar. Pollut. Bull., 2004, 49, 334-43.

19 KIPP EK., JARREL JL., GRIFFIN DW., LUKASIK J., JACUKIEWICZ J., ROSE JB. Preliminary evidence for human fecal contamination in corals of the Florida Keys, USA. Mar. Pollut. Bull., 2002, 44, 666-70.

20 KRIESEL I., KOLODNY Y., CAIRN WL., GALIL BS., SASSON Y., JOSHI AV., CANGELOSI A., BLATCHLEY ER., TENEYCK MC., BLACER MD., BRODIE P. The ternary effect for ballast water treatment. In: MATHEICKAL J., RAAYMAKERS S. Eds. INTERNATIONAL BALLAST WATER TREATMENT SYMPOSIUM, 2, London, 21-23 July 2003. Proceedings... London: Globallast Monograph Series, 2003, 15.

21 LAVOIE DM., SMITH LD., RUIZ GM. The potential for intracoastal transfer of nonindigenous species in the ballast water of ships. Estuarine Coast. Shelf Sci., 1999, 48, 551-64.

22 LefFler CE., ROgerson A., PAUL W., GERMAine G., ELLIOT M., ANTONELLI V., GRUBS S., CAMPBEL C., BEALL G., SALAMONE A. Electrosanitization of ballast water. In: MATHEICKAL J., RAAYMAKERS S. Eds. INTERNATIONAL BALLAST WATER TREATMENT, 2, London, 21-23 July 2003. Proceedings... London: Globallast Monograph Series, 2003, 15. 
23 MARTINS MT., PESSOA GVA., SANCHEZ PS., SATO MIZ., BRAYTON PR., COLWELL RR. Detection of Vibrio cholerae 01 in the aquatic environmental in Brazil employing direct immunofluorescence microscopy. World J. Microbiol. Biotechnol., 1993, 9, 390-2.

24 MARTINS MT., PESSOA GVA., SANCHEZ PS., SATO MIZ., COIMBRÃO CA., MONTEIRO CK., MARQUES E. Occurrence of $V$. cholerae $\mathrm{O} 1$ non-toxigenic in wastewaters from São Paulo, Brazil. Wat. Sci. Tech., 1991, 24, 363-6.

25 MATTÉ GR., MATTÉ MH., SATO MIZ., SANCHEZ PS., RIVERA IG., MARTINS MT. Potencially pathogenic vibrios associated with mussels from a tropical region on the Atlantic coast of Brazil. Intern. J. Food Microbiol., 1994, 116, 297-300.

26 McCALLUN HI., KURIS A., HARVELL CD., LAFFERTY KD., SMITH GW., PORTER J. Does terrestrial epidemiology apply to marine systems? Trends Ecol. Evol., 2004, 19, 585-91.

27 McCARTHY HP., CROWDER LB. An overlooked scale of global transport: phytoplankton species richness in ships' ballast water. Biol. Invasions., 2000, 2, 3212.

28 MCCARTHY SM., KHAMBATHY FM. International dissemination of epidemic Vibrio cholerae by cargo ship ballast and other non potable waters. Am. Soc. Microbiol., 1994, 60, 2597-601.

29 MESBAHI E. Latest results from testing seven different technologies under the EU MARTOB project - Where do we stand now? In: MATHEICKAL J., RAAYMAKERS S. Eds. INTERNATIONAL BALLAST WATER TREATMENT SYMPOSIUM, 2, London, 21-23 July 2003. Proceedings... London: Globallast Monograph Series, 2003, 15.

30 MILLS EL., LEACH JH., CARLTON JT., SECOR CI. Exotic species in the Great Lakes: a life history of biotic crises and antropogenic introductions. J. Great Lakes Res., 1993, 19, 1-57.

31 NATIONAL RESEARCH CONCIL. Commitee on Ship Ballast Operation. Stemming the tide: controlling introductions of nonindigenous species by ship's ballast water. Washington: National Academy Press, 1996. 141p.

32 NICHOLS FH., THOMPSON JK., SCHEMEL LE. Remarkable invasion of San Francisco Bay (California, USA) by the Asian clan Potomacorbula amurensis. II. Displacement of a former community. Mar. Ecol. Progr. Ser., 1990, 66, 95-101.

33 OCCHIPINTI-AMBROGI A., SAVINI D. Biological invasions as a component of global change in stressed marine ecosystem. Mar. Pollut. Bull., 2003, 46, 542-51. 
34 OEMCKE DJ. Future research on ballast water treatment - A technologist's view. In: PEDERSON J. Ed. NATIONAL CONFERENCE ON MARINE BIOINVASIONS, 1 , Cambridge, 1999. Proceedings... Cambridge: Massachusetts Institute of Technology, Sea Grant College Program, 1999. p.326-36.

35 PIERCE R., CARLTON JT., CARLTON D., GELLER JB. Ballast water as a vector for tin tinned transport. Mar. Ecol. Progr. Ser., 1997, 149, 295-7.

36 RIGBY G., HALLEGRAEFF G., TAYLOR A. Does heat offer a superior ballast water treatment option? In: MATHEICKAL J., RAAYMAKERS S. Eds. INTERNATIONAL BALLAST WATER TREATMENT SYMPOSIUM, 2, London, 21-23 July 2003. Proceedings... London: Globallast Monograph Series, 2003, 15.

37 RUIZ GM. Global spread of microorganisms by ships: Ballast water discharge from vessels harbors a cocktail of potential pathogens. Nature, 2000, 408, 49-50.

38 SHIGANOVA TA., MIRZOYAN ZA., STUDENIKINA EA., VOLOVIK SP., SIOKOUFRANGOU I., ZERVOUDAKI S., CHRISTOU ED., SKIRTA AY., DUMONT HJ. Population development of the invader ctenophore Mnemiopisis leidy in the Black Sea and in other seas of the Mediterranean basis. Mar. Biol., 2001, 139, 431-45.

39 SILVA JSV., FERNANDES FC., SOUZA RCCL., IARSEN KTS., DANELON OM. Água de Lastro e Bioinvasão. In: SILVA JSV., SOUZA RCCL. Eds. Água de Lastro e Bioinvasão. Rio de Janeiro: Interciências, 2004. p.1-10.

40 SUBBA RAO DV., SPRILES WG., LOCKE A., CARLTON JT. Exotic phytoplankton from ships' ballast waters: Risk potential spread to mariculture sites on Canada's east coast. Can. Data Rep. Fish Aquat. Sci., 1994, 37, 51.

41 THORNTON GA., CHAPMAN JE. The use of heat for ballast water disinfection the AquaTherm method. In: MATHEICKAL J., RAAYMAKERS S. Eds. INTERNATIONAL BALLAST WATER TREATMENT SYMPOSIUM, 2, London, 21-23 July 2003. Proceedings... London: Globallast Monograph Series, 2003, 15.

42 THRESHER RE., KURIS AM. Options for managing invasive species. Biol. Invasions, 2004, 6, 295-300.

43 WILLIANS RJ., GRIFFITHS FB., VAN DER WAL EJ., KELLY J. Cargo vessel ballast water as a vector for the transport of nonindigenous marine species. Estuarine Coast. Shelf Sci., 1988, 26, 409-20. 
C. K. Takahashi et. al. BALLAST WATER: A REVIEW OF THE IMPACT ON THE WORLD PUBLIC HEALTH. J. Venom. Anim. Toxins incl. Trop. Dis., 2008, 14, 3, p. 408

44 WRIGHT DA., DAWSON R., MACKEY TP., CUTLER HG., CUTLER SJ. Some shipboard trials of ballast water treatment systems in the United States. In: MATHEICKAL J., RAAYMAKERS S. EdS. INTERNATIONAL BALLAST WATER TREATMENT SYMPOSIUM, 2, London, 21-23 July 2003. Proceedings... London: Globallast Monograph Series, 2003, 15.

45 ZHANG S., CHEN X., YANG D., GONG W., WANG Q., XIAO J., ZHANG H., WANG Q. Effects of the chlorination treatment for ballast water. In: MATHEICKAL J., RAAYMAKERS S. Eds. INTERNATIONAL BALLAST WATER TREATMENT, 2, London, 21-23 July 2003. Proceedings... London: Globallast Monograph Series, 2003, 15. 